\title{
Nickel Free High Nitrogen Austenitic Steels
}

\author{
Peter J. UGGOWITZER, Ruth MAGDOWSKI and Markus O. SPEIDEL
}

Institute of Metallurgy, Swiss Federal Institute of Technology, ETH, Sonneggstrasse, CH-8092 Zurich, Switzerland.

(Received on September 29, 1995; accepted in final form on January 18, 1996)

\begin{abstract}
The paper presents the philosophy of the development and the resulting properties of a new austenitic stainless steel. The steel contains 15-18\% chromium, 3-6\% molybdenum, 10-12\% manganese, and about $0.9 \%$ nitrogen. The most important feature of this steel is the complete absence of nickel as alloying element. The austenitic microstructure is obtained exclusively by adding nitrogen. Besides being nickel free, the steel is further characterized by an excellent corrosion resistance, the absence of ferromagnetism, and outstanding mechanical properties. The unique combination of these properties makes this steel most interesting for its use in items which are in direct contact with the human body. By using these new steels, nickel allergy can be prevented.
\end{abstract}

KEY WORDS: steel development; nickel free stainless steels; superaustenitics; nickel allergy; allergic contact dermatitis.

\section{Introduction}

The element nickel, its alloys, and, in particular, the nickel containing austenitic stainless steels have been highly estimated and have been indispensable for the progress of the technology during the past 80 years. Our modern technology and high standard of living would not have been achieved without nickel containing alloys. We are confident that also in the near future, the outstanding role of nickel as alloying element will remain intact. However, an increasing number of allergic reactions due to nickel will cause some limitations of the use of nickel containing materials in favour of materials which do not emit any nickel when in contact with the human body.

There is a number of metals which serve as trace elements necessary for the normal function of the human organism. Such trace elements play an important role for the catalytic processes in a biological system. They are usually absorbed via food, drinking water, and breathing air. A lack of those trace elements can cause severe deficiency symptoms in the organisms. On the other hand, too high concentrations can also cause health problems. In the case of nickel, the direct contact with the skin or resorption or inhalation may be the reason for more or less heavy allergical reactions.

Allergy is a synonym for hypersensitivity. It is characterized by the fact that the human organism may suffer pathological reactions once it is repeatedly in contact with an antigenous substance. Basically all metals may cause an allergy. The element nickel, however, plays a specific role: First, it is a very potent allergen, and second, it is present almost everywhere. Nickel containing alloys are used for many items in daily life, such as coins, kitchen utensils, watches, style jewelry, buckles, and so on. Also as medical devices, nickel containing materials are often used, for example as prosthesis and implants.

In the case of nickel allergy, the nickel ions act as an antigenous substance which may cause cutaneous inflammations that are usually confined to those locations where a direct contact between skin and material has taken place. Typical reactions are swelling, reddening, eczema, and itching of the skin. As to style jewelry and watches, it is the aggressive sweat which causes the release of nickel ions. The metal ions are consequently absorbed by the epidermis when in direct contact with the corroding nickel containing material. The nickel ion is a semi-antigen which becomes an antigen after combining with a specific protein of the epidermis, and it then acts as allergen. Langerhans cells recognize the antigen and transport it to regional lymph nodes, where they settle in the paracortial areas. As soon as a specific threshold is reached, sensitization occurs combined with the formation of two new populations of lymphocytes. These include the so-called memory cells which store the memory of the contact allergen, and the so-called effector cells which actually trigger the allergic reaction in the moment of a new contact with the antigen. Once a person is sensitized by nickel ions, the effective allergic reaction can be triggered by a much smaller quantity than was necessary for the sensitization. In order to assess the allergologic effect of an alloy one must distinguish between its "potential of sensitization", i.e. the ability to sensitize a person which had not been allergic before, and its "potential of evocation", i.e. the ability of the alloy to evoke an allergic reaction in persons who already are sensitized.

While the potential of evocation can easily be tested with a group of already sensitized persons (patch test!), 
the testing of the potential of sensitization involves ethical problems, since one single test could sensitize a person for the rest of its life. Therefore, the European Parliament has appealed to the member states of the European Community to forbid or restrict the use of nickel containing alloys for specific applications (Directive 94/27/EC from 30 June 1994):

Nickel and its compounds may not be used: 1 . in post assemblies which are inserted into pierced ears and other pierced parts of the human body..., unless such post assemblies are homogeneous and the concentration of nickel is less than $0.05 \% ; 2$. in products intended to come into direct and prolonged contact with the skin as: earrings, necklaces, bracelets, chains, anklets, finger rings, wrist-watch cases, watch straps, rivets, tighteners, zips.... if the rate of nickel release from the parts of these products coming into direct and prolonged contact with the skin is greater than $0.5 \mu \mathrm{g} / \mathrm{cm}^{2} /$ week. Furthermore, products which are subject of points 1 and 2 may not be placed on the market unless they conform to the requirements set out in those points.

In order to test whether the proposed threshold of $0.5 \mu \mathrm{g} / \mathrm{m}^{2} /$ week is met, the so-called Dimethylglyoxim test (DMG) has been suggested. For this test, a cotton pad is soaked with an alcoholic solution of DMG and then rubbed on the test object. If the pad turns red, the threshold of $0.5 \mu \mathrm{g} / \mathrm{cm}^{2} /$ week is most probably exceeded. This method, however, is not fully accepted since for some sensitized persons even far smaller quantities than can be identified by the DMG test are sufficient to trigger an allergic reaction. In some cases, the extremely small quantities of nickel which eventually enter the body via food products can contribute to the allergic reaction. Successful therapies based on nickel free food (i.e. no cacao, chocolate, nuts, soy products, parsley, etc.) have confirmed this assumption.

The number of female persons affected by nickel allergy has doubled every one of the last few decades; among the male population, this number has only recently dramatically increased. Dermatologists assume a sensitization of about $20 \%$ of young women and $4 \%$ of young men. The main reason for nickel sensitization is the use of style jewelry, but also the daily use of many nickel containing utensils. Moreover, the overall environmental pollution is also proposed to be a significant reason for the ever increasing number of affected people. Various emissions result in the enrichment of nickel in water, soil, and plants, and thus, an enhanced uptake of nickel leads to more frequent allergic reactions.

The nickel allergy, and, in general, all allergies do not pose only a medical problem. Since healing costs of allergic diseases are nowadays increasing dramatically, the nickel allergy has become an economical issue: In Germany, for example, the overall increase in healing costs due to the ever increasing number of allergies has been reported to be about $50 \%$ between 1991 and 1993. In this connection, also the subject of "product liability" needs to be mentioned. One has to assume that in the future the producer of goods that may cause an allergy will be accountable.
The best method to limit nickel allergy is to omit any nickel containing materials which may eventually be in direct contact with the human body. There is no doubt that the use of nickel free products can largely prevent the occurrence of nickel allergy. The DMG test described above, however, is obviously not sufficient to distinguish whether the material is prone to trigger the allergy or not. From the medical point of view, there exists no single threshold value which will decide whether an allergic reaction will occur or not. Most decisive for the detrimental effect of a nickel containing alloy is to a large extent the personal disposition of the patient, including the aggressivity of the sweat or the permeability of the skin for nickel ions.

Iron base materials, i.e. steels, which are foreseen for applications where nickel allergy might occur, are not only required to be nickel free but, in addition, they also require a high corrosion resistance. This requirement arises from the fact that any compound used at or in the human body must be corrosion resistant. Moreover, even intentionally nickel free steels may contain up to $0.5 \%$ nickel which originates from the production process if iron scrab is used. In this case, then only a high corrosion resistance can ensure that no nickel ions will dissolve from the material when in contact with the organism.

Nickel free corrosion resistant steels have been produced for several decades all over the world. With only a few exceptions, these steels have a ferritic or martensitic microstructure and thus are ferromagnetic and, unfortunately often rather brittle. The urgent need for nickel free, corrosion resistant, and ductile steels has become an attractive and challenging task for the material scientists working in the field of steel research. Such steels have been developed in the Institute of Metallurgy of ETH Zurich. They have characteristically an austenitic microstructure which is in contrast to the ferritic and martensitic ones. The philosophy behind this alloy development and the achieved properties are presented in the following sections.

\section{Philosophy of Alloy Development}

According to the above mentioned requirements for a successful alloy, the following properties were to be achieved: Absence of nickel, absence of ferromagnetism, high corrosion resistance, good mechanical properties including in particular a high ductility, high fatigue endurance, high wear resistance, and, with regard to its eventual use for watches and jewelry, good polishing behavior.

The requirement for being non-ferromagnetic can easily be met by avoiding any ferritic phase. Thus, the goal was to develop a steel with austenitic microstructure without delta-ferrite. From the modified Schäffler diagram, ${ }^{1)}$ Fig. 1, follows that such alloys must have a sufficiently high nickel equivalent in order to obtain an alloy above the line austenite/duplex. Since this line has a slope of about 1 , the avoidance of delta-ferrite can be expressed in terms of alloying elements by the following simple equation: 


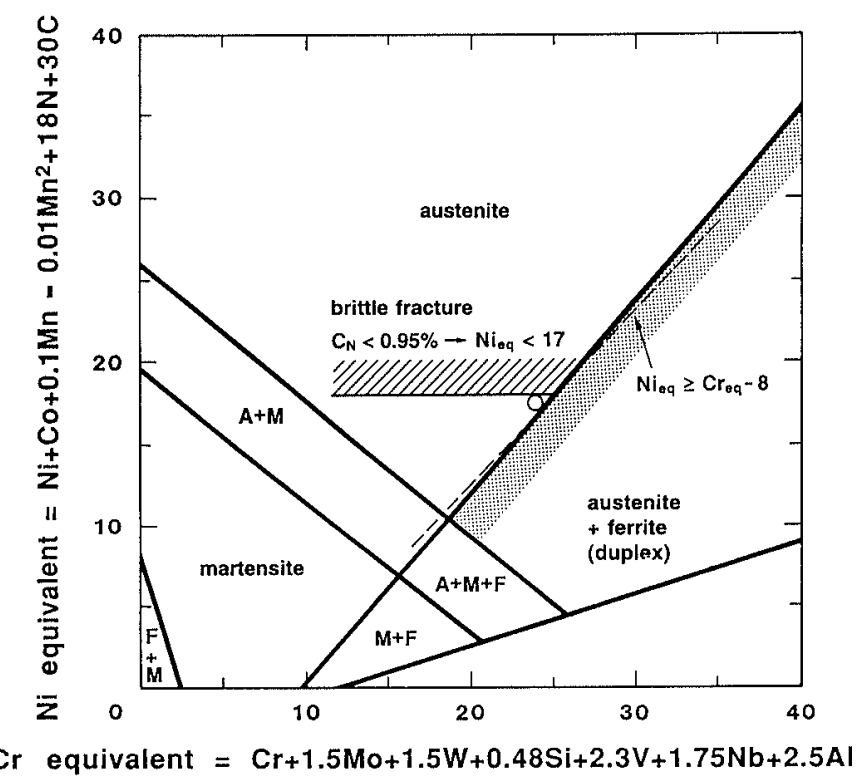

Fig. 1. In order to avoid delta-ferrite and brittle cleavage fracture, the nickel equivalent and thus the nitrogen concentration must be kept between well defined limits.

nickel equivalent $\mathrm{Ni}_{\text {eq }} \geq$ chromium equivalent $\mathrm{Cr}_{\text {eq }}-8$

with

$$
\begin{aligned}
\mathrm{Ni}_{\text {eq }}= & \% \mathrm{Ni}+\% \mathrm{Co}+0.1 \% \mathrm{Mn}-0.01(\% \mathrm{Mn})^{2} \\
& +18 \% \mathrm{~N}+30 \% \mathrm{C} \\
\mathrm{Cr}_{\text {eq }}= & \% \mathrm{Cr}+1.5 \% \mathrm{Mo}+1.5 \% \mathrm{~W}+0.5 \% \mathrm{Si} \\
& +2.3 \% \mathrm{~V}+1.75 \% \mathrm{Nb}
\end{aligned}
$$

This implies that for alloys which have a high chromium equivalent due to their chemical composition, a high nickel equivalent is necessary in order to achieve an austenitic microstructure. However, since for obvious reasons nickel is not an eligible choice, other alloying elements are necessary to stabilize the austenite. According to Eq. (1), possible austenite stabilizing elements are cobalt, carbon, and nitrogen. Out of these, cobalt is very similar to nickel in its allergologic behavior, and moreover, it is extremely expensive, and thus far from being acceptable. Carbon is very effective in increasing the nickel equivalent, however, already small additions of carbon decrease on alloy's corrosion and stress corrosion resistance and also enhance its tendency to form precipitates. Therefore, the carbon content should be kept below $0.1 \%$.

The best and only acceptable element to stabilize the austenitic phase is nitrogen. Thus, the newly developed nickel free steels are austenites in which nickel is fully replaced by nitrogen $\left(\mathrm{Ni}_{\mathrm{eq}}=18 \times \% \mathrm{~N}\right)$.

The corrosion resistance of nitrogen alloyed austenitic steels is mainly determined by the contents of chromium, molybdenum, and nitrogen. The pitting resistance equivalent (PREN) as given in Eq. (2) provides a first estimate of the resistance against localized corrosion in chloride solutions ${ }^{2)}$.

$$
\text { PREN }=(\% \mathrm{Cr}+3.3 \% \mathrm{Mo}+20 \% \mathrm{~N})
$$

The higher this equivalent is, the higher is the expected resistance against localized corrosion. According to Eq. (2), a high corrosion resistance can be achieved by well balanced alloying of chromium, molybdenum, and nitrogen. Obviously, a high nitrogen content has two beneficial effects: It suppresses the formation of deltaferrite, and, in addition, it improves substantially the pitting corrosion equivalent. However, it is essential to know that there is an upper limit for nitrogen alloying. This limitation is due to the fact that nickel free austenitic $\mathrm{Cr}-\mathrm{Mn}-\mathrm{N}-$ steels show a very characteristic fracture behavior: These alloys exhibit a ductile-to-brittle transition, which has usually been known only for ferritic materials. ${ }^{3)}$ The ductile-to-brittle transition temperature, DBTT, is strongly affected by the nitrogen concentration in the alloy. It can be predicted according to Eq. (3):

$$
\mathrm{DBTT}=300 C_{\mathrm{N}}-30 \quad[\mathrm{~K}]
$$

$C_{\mathrm{N}}:$ nitrogen content in mass $\%$

The application of nickel free steels at, in and close to the human body requires a ductile-to-brittle transition temperature distinctly below room temperature, i.e. about $-20^{\circ} \mathrm{C}$ would be acceptable. This implies, according to Eq. (3), that the nitrogen content must be restricted to about $0.95 \mathrm{wt} \%$. Such an upper limit for the nitrogen content has immediate consequences for both the nickel and the chromium equivalent: both equivalents are also limited by an upper value. Figure 1 illustrates the respective "forbidden" alloy compositions with respect to their nickel and chromium equivalents, marked by hatching. From this diagram it can be concluded that for the nitrogen content a maximum of about $0.9 \%$ has to be maintained. For chromium and molybdenum, whose alloy concentrations are interconnected by $(\% \mathrm{Cr}+1.5 \% \mathrm{Mo})$, the respective maximum is 24 .

Only as long as nitrogen is in solid solution, its desired effect on austenite stability and corrosion resistance is assured. A precondition for this beneficial influence is a high nitrogen solubility of the alloy. For high nitrogen contents such as $0.9 \%$, the solubility enhancing effect of chromium and molybdenum is not sufficient for a solid solution of nitrogen, thus, manganese must be added. However, too high manganese contents enhance the formation of intermetallic phases and diminish the corrosion resistance. ${ }^{4)}$ Therefore, the manganese content should be limited to clearly below $18 \%$. Preferably, a concentration of $10-12 \%$ seems to be optimal, since more than $10 \%$ manganese would slightly destabilize the austenite (see Eq. (1)).

Taking into account all the requirements and preconditions discussed above, a nickel free austenitic steel of the following composition is proposed:

$$
(\mathrm{Cr}+1.5 \mathrm{Mo}) \approx 23 \%, \quad \mathrm{Mn} \approx 11 \%, \quad \mathrm{~N} \approx 0.9 \%
$$

\section{Experimental Alloys}

Table 1 lists the chemical composition of the new nickel free alloys (alloy $\mathrm{A}$ to $\mathrm{G}$ ). Commercial alloys with low and high nickel content are included for comparison (P, $\mathbf{P}^{\prime}, \mathrm{P}^{\prime \prime}$ and $316 \mathrm{~L}, 904 \mathrm{~L}$, respectively).

The precondition of $(\% \mathrm{Cr}+1.5 \% \mathrm{Mo}) \leq 23$ permits 
Table 1. Chemical composition of all alloys investigated.

\begin{tabular}{cccccccccc}
\hline Alloy & Process & $\mathrm{Cr}$ & $\mathrm{Mo}$ & $\mathrm{Mn}$ & $\mathrm{Si}$ & $\mathrm{C}$ & $\mathrm{Ni}$ & $\mathrm{N}$ & $\mathrm{Cr}_{\mathrm{eq}}$ \\
\hline A & PESR & 17.1 & 3.2 & 11.4 & 1.2 & 0.008 & 0.01 & 0.92 & 22.5 \\
B & CPC & 17.2 & 3.3 & 12.3 & 0.48 & 0.020 & 0.04 & 0.85 & 22.6 \\
C & PESR & 17.3 & 3.9 & 11.0 & 1.1 & 0.017 & 0.01 & 0.88 & 23.6 \\
D & PESR & 16.4 & 4.2 & 11.8 & 1.6 & 0.009 & 0.04 & 0.98 & 23.5 \\
E & CPC & 17.1 & 4.3 & 11.2 & 0.79 & 0.020 & 0.04 & 0.91 & 23.9 \\
F & PESR & 14.6 & 5.9 & 11.2 & 1.4 & 0.016 & 0.03 & 0.85 & 24.1 \\
G & PEST & 11.8 & 7.8 & 11.1 & 1.5 & 0.017 & 0.01 & 0.80 & 24.2 \\
\hline P & ESR & 18.2 & 0.1 & 19 & 0.38 & 0.08 & 1.18 & 0.61 & 18.5 \\
P' & PESR & 17.9 & 1.9 & 18 & 0.52 & 0.06 & 0.13 & 0.91 & 21.0 \\
P" & ESR & 17.2 & 2.0 & 21 & 0.24 & $<0.03$ & 0.14 & 0.50 & 20.3 \\
\hline 316L & - & 16.8 & 2.21 & 1.62 & 0.23 & 0.016 & 12.1 & - & 20.2 \\
904L & - & 20.4 & 4.63 & 0.85 & 0.22 & 0.027 & 25.2 & 0.04 & 27.4 \\
\hline
\end{tabular}

PESR: Pressurized Electro-Slag-Remelting; CPC: Counter-Pressure-Casting.

basically a choice of the molybdenum concentration within wide limits. This has obviously an important impact on the corrosion properties, since, according to Eq. (3), a high molybdenum content increases the corrosion resistance. However, high molybdenum contents result in a higher tendency to sigma-phase formation, and thus it is important to find an optimal molybdenum concentration as a compromise.

The experimental alloys $A$ to $G$ were produced with systematically varied chromium and molybdenum concentration, e.g. from $(17 \% \mathrm{Cr}+3 \% \mathrm{Mo})$ up to $(11 \%$ $\mathrm{Cr}+8 \% \mathrm{Mo}$ ), by maintaining a manganese content of $11-12 \%$ and a nitrogen concentration of $0.9 \%$.

For the melting procedure under atmospheric pressure, the solubility for nitrogen is substantially below $0.9 \%$. Therefore, melting under increased nitrogen partial pressure became necessary. An alloy consisting of $17 \mathrm{Cr}-3 \mathrm{Mo}-11 \mathrm{Mn}$ under atmospheric pressure $(0.8 \mathrm{bar}$ nitrogen partial pressure) at $1600^{\circ} \mathrm{C}$ can dissolve only $C_{\mathrm{N}}=0.34 \%$ nitrogen. Only an increase of the partial pressure to a value of 6 bar dissolves sufficiently high nitrogen contents, namely $C_{\mathrm{N}}=0.88 \%$.

Two well known and well established procedures of the high pressure metallurgy were applied: The High Pressure-Electroslag-Remelting procedure ${ }^{5)}$ and the Counter-Pressure-Casting procedure. $\left.{ }^{6}\right)$ In all heats, the nickel concentration was kept well below $0.05 \%$ (see also European Directive, section 1). After a homogenization anneal, the bars were forged and heat treated.

\section{Metallography}

Two essential questions have to be answered in the following section:

(1) At which temperatures is the annealing of nickel free alloys to be carried out in order to obtain a homogeneous austenitic microstructure which is free of chromium nitrides and $\sigma$-phase?

(2) How stable is a homogenous austenitic microstructure with respect to precipitation at intermediate temperatures, as, for example, in the centre of large forgings during quenching.

Figure 2 shows a schematic illustration of the tem-

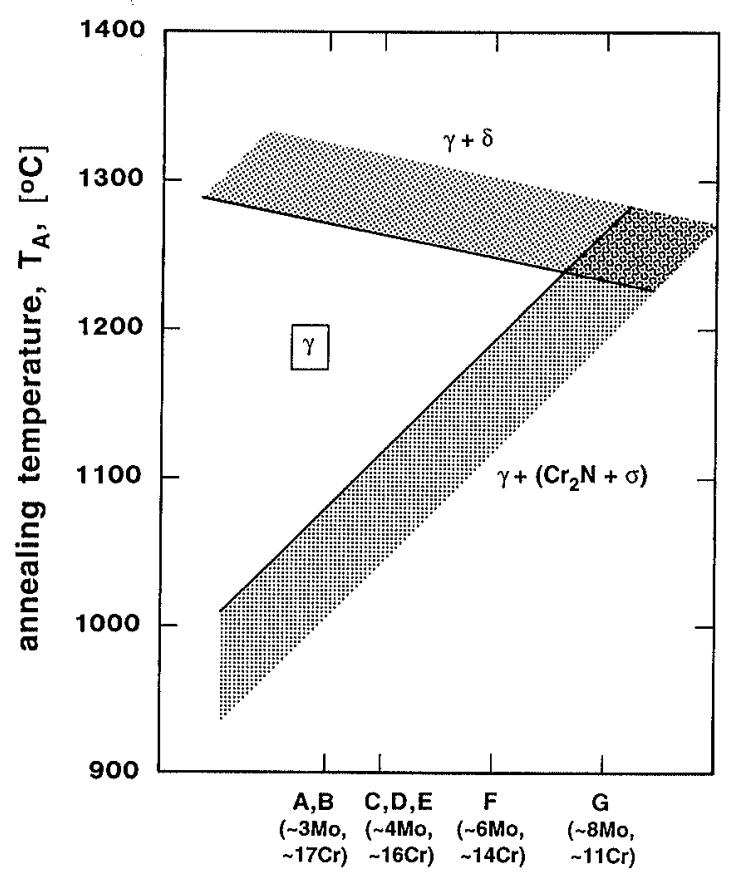

Fig. 2. The hatched areas limit the solution annealing temperatures which must be applied in order to obtain a precipitation free, austenitic microstructure.

perature range, where successful heat treatments with no precipitation can be performed. Obviously, a solution annealing treatment requires a strict temperature adjustment: too low temperatures result in chromium nitride and $\sigma$-phase formation, whereas too high temperatures result in delta-ferrite. Strikingly, the critical solution annealing temperature, represented by the line $\gamma /\left(\gamma+\mathrm{Cr}_{2} \mathrm{~N}+\sigma\right)$ in Fig. 2 is considerably higher for the high molybdenum containing alloys than for the medium molybdenum containing ones: $3 \%$ Mo containing alloys must be annealed at $1080-1130^{\circ} \mathrm{C}$ in order to obtain a precipitation free microstructure, $4 \%$ Mo alloys at $1130-1180^{\circ} \mathrm{C}$, and $6 \%$ Mo alloys at at least $1200^{\circ} \mathrm{C}$. Those alloys which contain $8 \%$ Mo never exhibit a precipitation free microstructure. Figures 3 through 6 show various examples of micrographs for possible microstructures.

In order to discuss the precipitation of chromium 


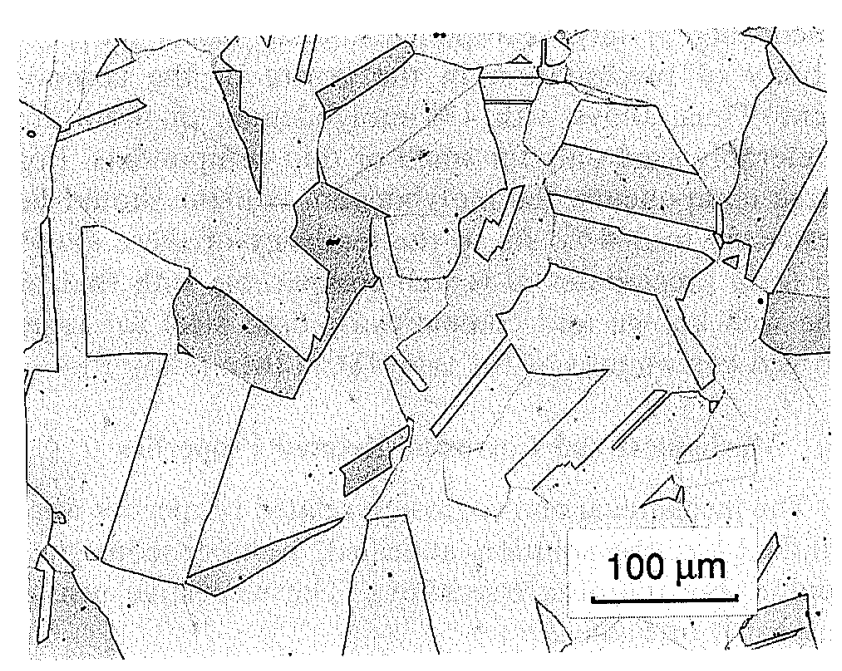

Fig. 3. Alloy $\mathrm{A}(17.1 \mathrm{Cr}, 3.2 \mathrm{Mo})$; Solution annealing treatment at $1100^{\circ} \mathrm{C} / \mathrm{I} \mathrm{h} / \mathrm{H}_{2} \mathrm{O}$ leads to precipitation free microstructure.

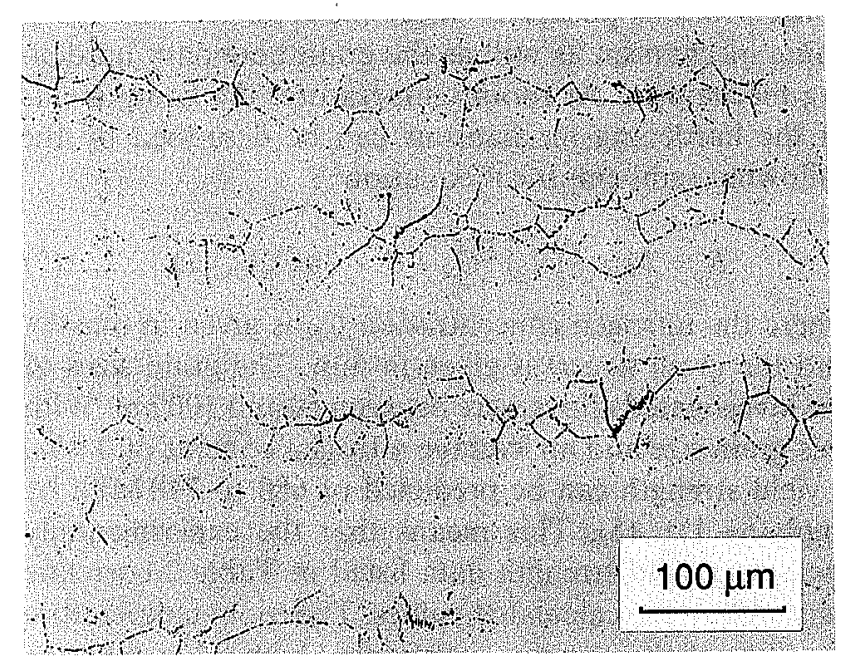

Fig. 4. Alloy $\mathrm{C}(17.3 \mathrm{Cr}, 3.9 \mathrm{Mo})$; Formation of $\mathrm{Cr}_{2} \mathrm{~N}+\sigma$ in the molybdenum rich segregated zones; precipitations primarily at grain boundaries. Annealed at $1100^{\circ} \mathrm{C} /$ $1 \mathrm{~h} / \mathrm{H}_{2} \mathrm{O}$.

nitride $\mathrm{Cr}_{2} \mathrm{~N}$ and $\sigma$-phase, the synergistic effects of the alloying elements chromium, molybdenum, and nitrogen must be taken into account. ${ }^{2)} \mathrm{A}$ high chromium content increases the solubility for nitrogen and thus lowers the nitrogen activity. As a consequence, the $\gamma /\left(\gamma+\mathrm{Cr}_{2} \mathrm{~N}\right)$ transition is shifted towards lower temperatures. On the other hand, a reduction in chromium, for examples from $17 \%$ (alloy $\mathrm{A}$ in Table 1) to $8 \%$ (alloy $\mathrm{G}$ in Table 1), results in an increase of the critical temperature for $\mathrm{Cr}_{2} \mathrm{~N}$-precipitation. Molybdenum increases the nitrogen solubility, too, but not to the same extent as chromium does. Therefore, a full compensation in solubility by an increase in molybdenum from 3 to $8 \%$ cannot be expected. However, the precipitation of $\sigma$-phase is clearly more affected by molybdenum than by chromium: $1 \%$ molybdenum shifts the $\gamma /(\gamma+\sigma)$ transition temperature by about 70 degrees, while $1 \%$ chromium shifts it only by about 45 degrees. ${ }^{2)}$ Thus, the transition temperature is very high for high molybdenum alloys.

An alloy's tendency to precipitate $\mathrm{Cr}_{2} \mathrm{~N}$ is not

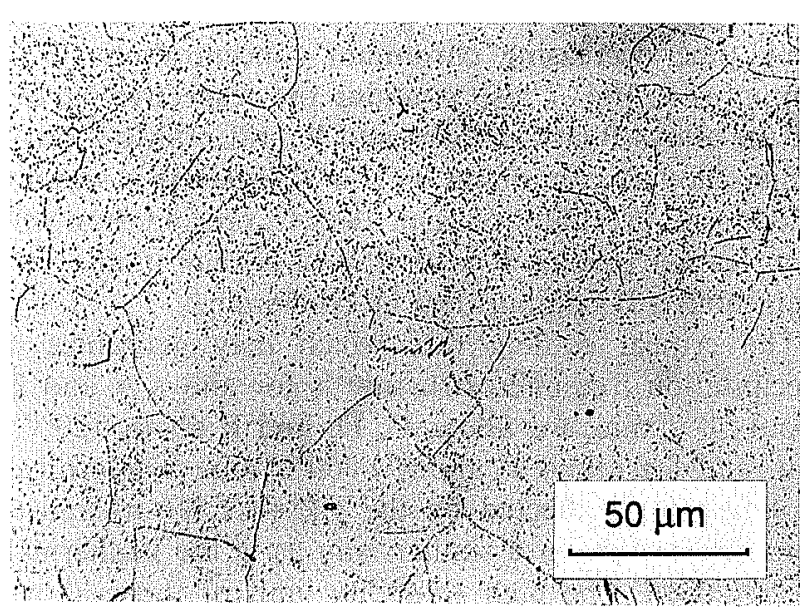

Fig. 5. Alloy F (14.6Cr, 5.9Mo); $\left(\mathrm{Cr}_{2} \mathrm{~N}+\sigma\right)$-precipitations at grain boundaries and within the grains. Annealed at $1100^{\circ} \mathrm{C} / 1 \mathrm{~h} / \mathrm{H}_{2} \mathrm{O}$.

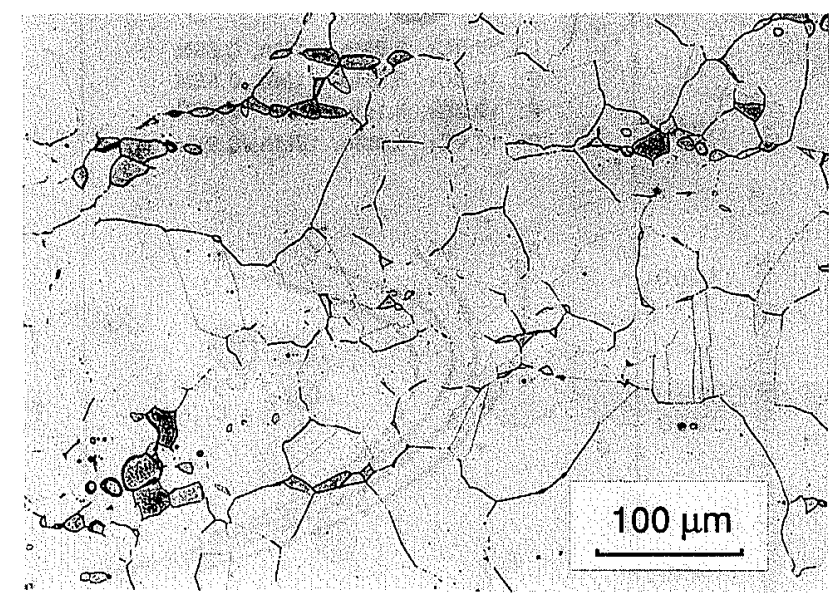

Fig. 6. Alloy $\mathrm{G}(11.8 \mathrm{Cr}, 7.8 \mathrm{Mo})$; Formation of $\delta$-ferrite and $\left(\mathrm{Cr}_{2} \mathrm{~N}+\sigma\right)$-precipitations. Annealed at $1250^{\circ} \mathrm{C} / 1 \mathrm{~h} /$ $\mathrm{H}_{2} \mathrm{O}$.

independent of the formation of sigma-phase. The reason for this observation is due to the important role of nitrogen for the $\sigma$-formation: $1 \%$ nitrogen lowers the $\gamma /(\gamma+\sigma)$ transition temperature by about $300^{\circ} \mathrm{C}$. If, for example, a chromium nitride is formed, then the nitrogen concentration in the matrix just near the nitride is lowered and thus, the austenite is destabilized, i.e. $\sigma$-phase will be formed. $\sigma$-phase, however, cannot dissolve any nitrogen, therefore nitrogen will concentrate around the $\sigma$-phase, causing $\mathrm{Cr}_{2} \mathrm{~N}$-precipitation, and so on. Obviously, there is an interactive and alternating formation of $\mathrm{Cr}_{2} \mathrm{~N}$ and $\sigma$-precipitations, independent of whether the first precipitate was nitride or $\sigma$-phase. ${ }^{7)}$ It is important to note that molybdenum tends to segregate, therefore precipitations are usually found in segregation zones (see Fig. 4).

The major effect of the alloying elements chromium and molybdenum is observed not only in the transition curves for precipitation, as shown above, but also in the time-temperature-precipitation diagrams for the temperature range below the $\gamma /\left(\gamma+\mathrm{Cr}_{2} \mathrm{~N}+\sigma\right)$ solubility limit. The isothermic TTP-diagrams in Fig. 7 illustrate that the time to the very first precipitation is shifted towards 
shorter times with increasing molybdenum and, at the same time decreasing chromium concentrations. For comparison, Fig. 7 also contains the respective curves for the alloys $\mathrm{P}(18 \mathrm{Cr} 18 \mathrm{Mn})$ and $\mathrm{P}^{\prime}(18 \mathrm{Cr} 18 \mathrm{Mn}+\mathrm{Mo})$. While alloy $\mathrm{P}$, containing $0.61 \% \mathrm{~N}$, exhibits a weaker tendency to precipitation than alloy $\mathrm{C}$, precipitation will occur earlier in alloy $\mathrm{P}^{\prime}$ with $0.91 \% \mathrm{~N}$ than in alloy $\mathrm{C}$, even though $\mathrm{P}^{\prime}$ contains less molybdenum.

The critical cooling rate which may guarantee a precipitation free microstructure is for alloys $\mathrm{A}$ and $\mathrm{B}$ about $50^{\circ} \mathrm{C} / \mathrm{min}$, for alloys $\mathrm{C}, \mathrm{D}$, and $\mathrm{E}$ about $120^{\circ} \mathrm{C} /$ min, and for alloys $\mathrm{F}$ about $1000^{\circ} \mathrm{C} / \mathrm{min}$. The critical cooling rate is affected by the $\gamma /\left(\gamma+\mathrm{Cr}_{2} \mathrm{~N}+\sigma\right)$-transition temperature in a similar way as is the isothermal precipitation. The high solubility limit of those alloys which contain high molybdenum (see Fig. 2) increases their tendency to form precipitates. Therefore, during

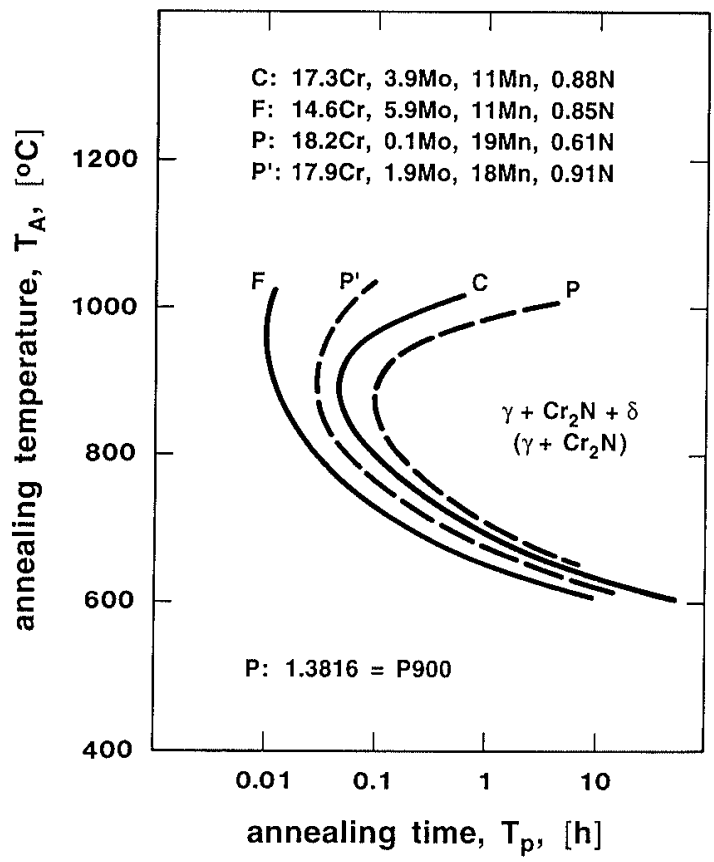

Fig. 7. Isothermal time-temperature-precipitation diagram. Increasing molybdenum enhances the $\left(\mathrm{Cr}_{2} \mathrm{~N}+\sigma\right)$-formation. quenching of large components, there exists the possibility of precipitation in the centre of the component. Thus, alloys with $4 \%$ molybdenum or more are preferably used only for small or thin components. For large components, the molybdenum content should be restricted to $3-4 \%$. As to the tendency of these alloys to form precipitates, it is well comparable with that of the well known and commercially used steel for large forged compounds of the type $18 \mathrm{Cr} 18 \mathrm{Mn}$ (alloy P).

\section{Mechanical and Corrosion Related Properties}

The mechanical and corrosion related properties were studied for the solution annealed, homogeneous austenitic, precipitation free alloys. The respective results are listed in Table 2.

As expected, the values for both yield strength and tensile strength of the nickel free nitrogen alloyed steels are clearly higher than those of the conventional austenitic steels AISI $316 \mathrm{~L}$ and 904L. The high nitrogen concentrations positively affect the solid solution hardening mechanism as well as the grain boundary hardening mechanism. At room temperature, the components of the hardening mechanisms can be described by the following semi-empirical equation ${ }^{8)}$ :

$$
R_{\mathrm{p}}=145 \sqrt{1+15 C_{\mathrm{N}}}+\left(8+38 C_{\mathrm{N}}\right) / \sqrt{D}
$$

where the nitrogen concentration $C_{N}$ is given in mass \% and the grain size $D$ is given in $\mathrm{mm}$. The grain sizes of the investigated alloys were between 50 and $100 \mu \mathrm{m}$. With this grain size and an average nitrogen content of $0.9 \%$, a yield strength can be predicted of 680 to $740 \mathrm{MPa}$ by applying Eq. (5). This means that the experimentally measured yield strength data listed in Table 2 correlate very well to the calculated values. The room temperature ductility of the alloys is satisfyingly high. However, the ductile-to-brittle transition has to be taken into account. Indeed, as shown in Fig. 8, for alloys $\mathrm{C}$ and $\mathrm{F}$ this transition occurs at about $-2^{\circ} \mathrm{C}$, as predicted by $\mathrm{Eq}$. (3).

The results of corrosion tests prove an excellent corrosion resistance of the nickel free austenites exposed to chloride solutions. Compared to conventional alloys

Table 2. Mechanical and corrosion properties of all alloys investigated in the solution annealed, precipitation free condition.

\begin{tabular}{c|ccccc|ccc}
\hline Alloy & $\begin{array}{c}R_{\mathrm{p} 0.2} \\
(\mathrm{MPa})\end{array}$ & $\begin{array}{c}R_{\mathrm{m}} \\
(\mathrm{MPa})\end{array}$ & $\begin{array}{c}A_{5} \\
(\%)\end{array}$ & $\begin{array}{c}Z \\
(\%)\end{array}$ & $\begin{array}{c}A_{\mathrm{v}}(\mathrm{RT}) \\
(\mathrm{J})\end{array}$ & $\begin{array}{c}\text { PREN } \\
(-)\end{array}$ & $\begin{array}{c}T_{\text {ccc }} \\
\left({ }^{\circ} \mathrm{C}\right)\end{array}$ & $\begin{array}{c}E_{\mathrm{p}} \\
\left(\mathrm{mV} \mathrm{V}_{\text {SHE }}\right)\end{array}$ \\
\hline $\mathrm{A}$ & 672 & 1021 & 62 & 68 & 220 & 46.1 & $32+37$ & $>1200$ \\
$\mathrm{~B}$ & 663 & 981 & 57 & 62 & 260 & 45.1 & $22+27$ & $>1200$ \\
$\mathrm{C}$ & 692 & 1049 & 66 & 72 & 226 & 47.8 & $37+42$ & $>1200$ \\
$\mathrm{D}$ & 724 & 1110 & 60 & 68 & 185 & 49.9 & $32+37$ & $>1200$ \\
$\mathrm{E}$ & 707 & 1073 & 53 & 62 & 246 & 49.5 & $37+42$ & $>1200$ \\
$\mathrm{~F}$ & 710 & 1042 & 66 & 70 & 200 & 51.1 & $37+42$ & $>1200$ \\
\hline $\mathrm{P}$ & 560 & 921 & 67 & 66 & $>300$ & 29.5 & $<-3$ & $120+160$ \\
$\mathrm{P}^{\prime}$ & 658 & 1046 & 62 & 66 & 200 & 40.6 & $<-3$ & $>1200$ \\
$\mathrm{P}^{\prime \prime}$ & 494 & 908 & 63 & 68 & 280 & 32.8 & $<-3$ & $170+230$ \\
\hline $316 \mathrm{~L}$ & 240 & 517 & 60 & 72 & $>300$ & 25 & $<-3$ & $480+560$ \\
$904 \mathrm{~L}$ & 255 & 535 & 62 & 74 & 300 & 35 & $-3+0$ & $960+1050$ \\
\hline
\end{tabular}

$T_{\text {ccc }}$ : critical crevice corrosion temperature; aerated $6 \% \mathrm{FeCl}_{3}$-solution.

$E_{\mathrm{p}}$ : pitting potential; $1 \mathrm{M} \mathrm{NaCl}, 37^{\circ} \mathrm{C}, \mathrm{Ar}$. 


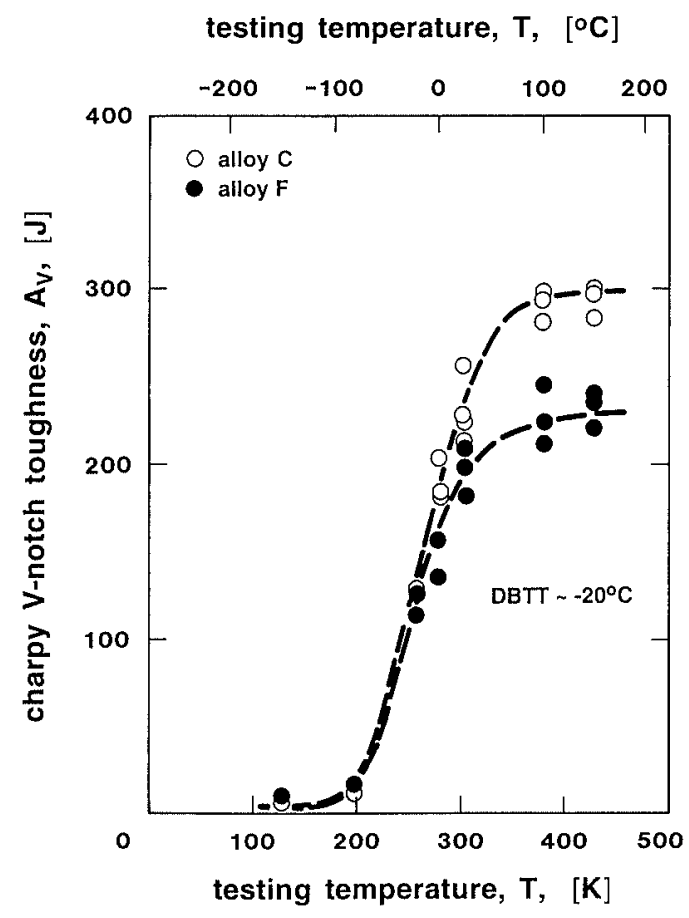

Fig. 8. The ductile-to-brittle transition is observed at about $-20^{\circ} \mathrm{C}$. At room temperature the alloys are very ductile.

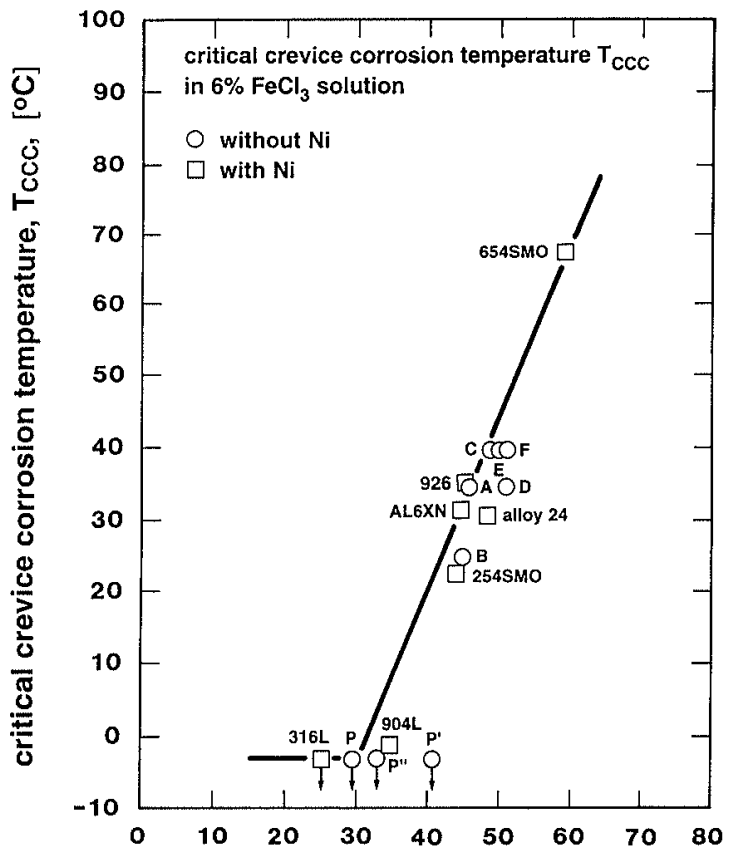

crevice corrosion equivalent, $[\% \mathrm{Cr}+3.3 \% \mathrm{Mo}+20 \% \mathrm{~N}]$

Fig. 9. The new Ni-free alloys $\mathrm{A}$ to $\mathrm{F}$ exhibit a high resistance to localized corrosion. The nickel free alloys with high manganese contents are not as resistant.

which are often used in the watch and medical device industry, such as AISI316L and $904 \mathrm{~L}$, the new steels are clearly more corrosion resistant. Figure 9 illustrates a comparison by showing the critical crevice corrosion temperature in a standard $\mathrm{FeCl}_{3}$-solution of both the conventional austenitic steels and the new nickel free steels. Apparently, the new steels exhibit a resistance to crevice corrosion similar to that of high nickel containing superaustenites. In contrast to this excellent behavior, the nickel free alloys with high manganese contents, however, are clearly less corrosion resistant $\left(\mathrm{P}, \mathrm{P}^{\prime}, \mathrm{P}^{\prime \prime}\right)$, as demonstrated for both the critical crevice corrosion temperature and the pitting potential. Thus, obviously high manganese contents of more than $10 \%$ adversely affect the corrosion properties. A quantitative investigation of this effect is currently under way.

Further properties which are important for the successful application of the new alloys at or in the human body are polishability, wear resistance, and endurance limit. As to the polishing properties, a subjective judgement attests the nickel free steels a good performance. Also the wear resistance, tested according to ASTM G65 (rubber-wheel-test) was measured to be extremely high compared to conventional austenitic and duplex steels. Fatigue tests are currently performed; first test results in air exhibit a promising behavior. Also with regard to corrosion fatigue, good results appear to be likely.

\section{Summary}

A new type of austenitic steels has been developed at the Institute of Metallurgy of ETH Zurich. These steels are characterized by an outstanding combination of the following properties: Absence of nickel, high corrosion resistance, absence of ferromagnetism, and good ductility.

The steels contain 15-18\% chromium, 3-6\% molybdenum, $10-12 \%$ manganese, and about $0.9 \%$ nitrogen. They are free of nickel which is fully in accordance with the European Directive 94/27/EC of June 30, 1994, concerning the use of nickel containing alloys.

Due to their high contents of chromium, molybdenum, and nitrogen, these steels are highly corrosion resistant. Therefore, they do dissolve neither in human organic fluids nor in sweat and thus do not emit any ions to the human body to any measurable degree. Their corrosion resistance in chloride solutions increases with increasing pitting resistance equivalent PREN $=\% \mathrm{Cr}+3.3 \% \mathrm{Mo}+$ $20 \% \mathrm{~N}$. Conventional stainless steels typically have a pitting resistance equivalent of about 20 to 35 . The newly developed nickel free steels, however, have a PREN-value of 45 and more, thus their corrosion resistance is by far superior to that of conventional steels.

The new steel is non-magnetic. This can be ensured by keeping the nickel equivalent--achieved and maintained by nitrogen-equal or higher than the chromium equivalent minus $8\left(\mathrm{Cr}_{\mathrm{eq}}-8\right)$. Thus, the austenite is sufficiently stabilized and no ferromagnetic delta-ferrite is formed.

The new steel has a good ductility. This can be achieved by keeping the nitrogen content below $0.95 \%$, since higher nitrogen concentrations would result in brittle cleavage fracture.

\section{Acknowledgements}

The authors gratefully acknowledge the help of Firma Vereinigte Schmiedewerke, VSG, Essen, with the production of the alloys by the Pressurized-Electro-SlagRemelting procedure. They also acknowledge the production of some alloys by the Counter-PressureCosting procedure, performed at the Bulgarian Academy 
of Sciences.

\section{REFERENCES}

1) M. O. Speidel and P. J. Uggowitzer: Proc. Materials Week'92, Chicago, ed. by R. A. Lula, ASM Int., (1993), 135.

2) P. J. Uggowitzer, R. Magdowski and M. O. Speidel: Metall. Ital., 84 (1994), 6-7, 347.

3) P. J. Uggowitzer, N. Paulus and M. O. Speidel: Proc. Conf. Application of Stainless Steel 92, Stockholm, ASM Int., (1992), 62.

4) A. Cigada, G. Rondelli, B. Vicentini, F. Brunella and G. Dallaspezia: Proc. of 185th Meeting, Electrochem. Soc.,
California, (1994).

5) J. Menzel, G. Stein and P. Dahlmann: Proc. Int. Conf. High Nitrogen Steels, HNS 92, Stahl \& Eisen, Aachen, (1992), 365.

6) T. Rashev: Proc. Int. Conf. High Nitrogen Steels, HNS 92, Stahl \& Eisen, Aachen, (1992), 271.

7) C. Solenthaler, P. J. Uggowitzer and M. O. Speidel: submitted to ISIJ Int.

8) M. Diener, B. Irimescu, H. Sun, P. J. Uggowitzer and M. O. Speidel: Stickstofflegierte Stähle, Materials Research Comm. Vol. 4, ed. by M. O. Speidel und P. J. Uggowitzer, Thubal-Kain, (1991), 123. 